\section{Holocaust Education in Turkey: Past, Present, and Future}

\author{
Pınar Dost-Niyego' \\ ilker Aytürk²
}

Contemporary Review of the Middle East 3(3) 250-265

(C) 2016 SAGE Publications India Private Limited SAGE Publications sagepub.in/home.nav DOI: | $0 . \mid$ | 77/23477989|665458| http://cme.sagepub.com

\begin{abstract}
The article emphasizes on the challenges stemming from writing the history of a multicultural, multiethnic, and multireligious, post-imperial society from the perspective of a nation-state that strives for sweeping all differences under the carpet. It focuses on the complete absence of Holocaust education in Turkish public curricula. There are various challenges that future Holocaust educators do and may face in Turkey and the article strives to address some of them. It concludes that Holocaust education can contribute to memory studies, citizenship, and human rights education in Turkey, empowering an already existing public debate on confronting Turkey's troubled past.
\end{abstract}

\title{
Keywords
}

Holocaust education, Turkey, Turkey-Israel, Turkish attitude toward Jews, Second World War, Antisemitism, Memory

In this article, we aim to focus on Holocaust education (or lack thereof) in Turkey. First, we will describe the beginnings of Holocaust education globally and explain how and why different countries tailored different approaches to Holocaust education according to their own needs and particular historical background. Next, we will provide a brief overview of modern Turkish attitudes toward the Jewish people, Holocaust, and the State of Israel and this will partly include the history of the Jews in the Turkish Republic, that is, their relationship with the Turkish nation-state. We will also dwell on Turkish policy during the Second World War vis-à-vis Jews

\footnotetext{
I Independent Historian and Educator, Member of Istanbul Bilgi University Study Group on Jewish Communities in Turkey (YATOÇ), Turkey.

${ }^{2}$ Department of Political Science and Public Administration, Bilkent University, Ankara, Turkey.
} 
(including Turkish Jews), who were trying to escape the Nazi slaughter in Europe as modern narratives of Turkey's recent past cannot be studied without understanding Turkish perception and memory of the Holocaust and the Jews.

Next, the main body of the article will turn the spotlights on history education and textbooks in Turkey. Primarily, we will put the emphasis on the challenges stemming from writing the history of a multicultural, multiethnic, and multireligious, post-imperial society from the perspective of a nation-state that strives for sweeping all differences under the carpet. Currently, Holocaust education hardly exists in Turkish public curricula. There are various challenges that future Holocaust educators do and may face in Turkey and we plan to address those. Finally, we will conclude by showing how Holocaust education could contribute to memory studies, citizenship, and human rights education in Turkey, empowering an already existing public debate on confronting Turkey's troubled past.

"Holocaust," "Shoah," or "genocide of the Jews" is the systematic extermination of approximately six million Jews in the Nazi-occupied Europe during the Second World War by the Nazi Germany and its allies. Not only the Jews, but also the Roma, Sintis, Poles, homosexuals, mentally ill and disabled, and physically disabled people were either exterminated or treated terribly under the Nazi occupation. Under the enormity of this crime, the United Nations adopted the Convention on the Prevention and Punishment of the Crime of Genocide on 9 December 1948. The acknowledgment of the Holocaust also brought with it a widespread banning of Antisemitism (prejudice against or hatred of Jews), which was a widely held belief and an ideology before the war throughout the Western world.

Until the 1970s - with West Germany as one big exception - the Holocaust studies in the world were premature and a global memory of the Holocaust did not exist at all. Negligence of the crime was such that stories told by the survivors fell on deaf ears and they were hardly able to find publishing houses and media to circulate their recollections. To give particular examples, in post-war France, only the victories of the Resistance, Gaullism, and republican values of equality, liberty, and fraternity found their way into the public construction of the memory of the Second World War, paving the way for reintegration of the Jews into French society (Kriegel, 2005, p. 62; Wieviorka, 1997, p. 280; 2008). Likewise, in the United States of America, Holocaust did not even appear in the public agenda for a number of decades because the national history narrative was dominated by American values and how those values helped them win the war against the Nazis (Novick, 1999; Rosenfeld, 1995). In pre-Israel Palestine and post-1948 State of Israel, Holocaust memory was publicly ignored and sometimes suppressed because the newly established state aimed to get rid of the self-perceived image of a weak Jew who was led to slaughter like lambs (Ofer, 2009, p. 6). ${ }^{1}$ Indeed, until the 1970s, priority was given to stories of resistance in the Israeli memory of the Holocaust, as exemplified by the uprising in the Warsaw Ghetto (Wieviorka, 1997, p. 280).

Germany, due to the weight of its role in the making of the Holocaust, was a big exception, as the German state and the German society were forced to deal with the Holocaust memory right from the beginning. However, even in Germany, as German lands were divided into two states, there were also two distinct paths of facing the recent past. The German Democratic Republic (GDR) or the East 
Germany identified with anti-fascist and socialist values and unilaterally absolved itself from the crimes of the Nazi regime by putting all the responsibility on the shoulders of the Federal Republic of Germany (FRG) or West Germany, which it regarded as the continuation of the Third Reich (Kosmola, 1999, p. 806). West Germany, on the other hand, dared to face its responsibility in the Holocaust, partly because the FRG was under pressure from the Allied occupation forces to do this. The crimes of the Nazis and the Holocaust were immediately included in school textbooks with one caveat, that is, it was Hitler and the Nazi party only who were blamed in the public narrative (ibid., p. 807), while the German society was portrayed as helpless victims of the very same perpetrators. The official line also insisted that the majority of the German people were unaware of the extermination of the Jews. Until the mid-1960s de-Nazification was weak in the West and a real, societal reckoning with the Holocaust did not happen.

However, in Germany and elsewhere, some landmark events contributed to a new atmosphere of Holocaust awareness. Among those events we may count the Eichmann Trial in 1961-1962, Auschwitz Trial in Frankfurt in 1963-1965, Holocaust miniseries broadcast on the American TV channel NBS in 1978, and the emergence of a number of pseudo-academic Holocaust deniers in the 1960s and 1970s. In this new atmosphere of Holocaust awareness, two important steps were taken. First, there was now an acknowledgment of the fact that the Holocaust could not be blamed only on Hitler and the Nazis but larger sections of the German society as well as occupied nations were also aware of the crimes and many of them actually participated in the extermination of the Jews. Second, up to this point in post-war world, only West Germany had integrated Holocaust education into its public education system and even there from a "blame-Hitler" perspective but from the mid-1980s, German textbooks began to include a more pluralistic approach to the study of the Holocaust and national socialism. At the same time, Holocaust also began to come up in national debates over public education globally. Nevertheless, it was only in the 1990s that the Holocaust was fully integrated into public curricula in the Western world. The central and eastern European states were going to follow suit after their liberation from the Soviet yoke in the 1990s.

Today, Holocaust education is not limited to history courses in the Western world, but it repeatedly appears in elementary to high school curricula in various courses and topics. New teaching methods are rigorously applied so that teaching of historical events is not by rote learning. The new pedagogical approach includes visits to museums and memory sites, meetings with Holocaust survivors, and commemorating the Holocaust Remembrance Day. Needless to say, despite the lack of resources and time, this kind of a new approach requires massive retraining of teachers to provide them with necessary tools and library and online sources.

After a few decades of Holocaust education and research on the subject, specialized institutions created a number of guidelines for educators. ${ }^{2}$ While there are various issues these guidelines are dealing with, we would like to emphasize four of them. The first stresses the need for teachers to depict Jews not only as victims of the Holocaust, but also as inseparable members of and participants in national cultures and as people who contributed immensely to the making of the modern world. Second, teachers are also encouraged to focus not only on what happened 
between 1933 and 1945, but to emphasize the root causes of genocide, to increase awareness about the environment that gave birth to Antisemitism and mass atrocities, and to discuss with students possible ways of addressing discrimination and human rights violations. Third, we are currently witnessing the passing of the last generation of Holocaust survivors and we will soon have to address Holocaust, when its actual witnesses are no longer with us. As a result, the new frontier in the teaching of the Holocaust is going to involve technology and digitalization of memory to an unprecedented degree. Finally, during the last decade the most prominent discussion and still a contemporary trend in teaching the Holocaust is to attempt to understand it from the vantage point of individual countries, by seeing mass atrocities and genocide under the light — and sometimes darkness - of each national experience. This new perspective employs Holocaust studies as the starting point to face uncomfortable memories of the past in those local contexts (Boix-Mansilla, 2000; Fracapane and $\mathrm{Ha} \beta$, 2014). ${ }^{3}$ To summarize, Holocaust education in the contemporary world draws heavily on lessons learnt from the Holocaust in defining the current aims of Holocaust education. Among those aims we may count:

1. to prevent future occurrences of genocide and mass atrocities,

2. to raise a new generation of individuals who take personal and communal responsibility and do not become a blind follower of the crowd,

3. to recognize the fragility of democracies particularly if certain institutions (courts, universities, hospitals, and houses of worship) and professional groups (judges, police, doctors, academics, teachers, politicians, and religious leaders) fail to support democratic values,

4. to detect and prevent the formation of mechanisms, ideologies, policies, and movements that could lead to genocide, and

5. to raise awareness about discrimination in our daily lives.

Guided by these premises and values as well as an eye toward these goals, the study of the Holocaust struck roots first in the American academia, gradually making the leap to European campuses. Today many universities in the western world boast a chair, center or an undergraduate or a graduate program in what came to be known as Holocaust Studies. As a matter of fact, academic study of the Holocaust paved the way for and contributed main research tools and methodology to the academic study of other genocides.

\section{Holocaust and the Turkish Republic: History and Memory}

The transformation from empire to republic was a watershed in the lives of Jews living on what had now become the territory of the Republic of Turkey. The difference was being tolerated in a multiethnic and multireligious Ottoman Empire, where under the framework of the millet system, each religious community was recognized as an autonomous self-governing unit. However, the republic was founded as a nation-state, and like all other nation-states at the time, it demanded 
assimilation into a national whole, the so-called new Turkish citizenship, which was imagined as a secular monolithic identity. Despite its claim to be a civic, nonethnic model of citizenship, which provided a common identity to all citizens and equality before law, in practice non-Muslim citizens of Turkey could not enjoy full equality. Although there were no legal barriers, Jews, just like Greeks and Armenians, were not allowed to join civil and military bureaucracy (Kurban, 2007). ${ }^{4}$ Furthermore, there were official and popular pressure on the Turkish Jews to give up speaking their traditional languages, Ladino and French. ${ }^{5}$

Another worrisome development in the 1930s was the emergence of a small but vocal group of antisemites (Bali, 2013a, 2013b), who imported antisemitic themes and literature from France and Germany. ${ }^{6}$ These antisemitic stereotypes gradually seeped into mainstream Turkish press (Bali, 2013b, p. 216; Koçak, 2003 , p. 502), which published derogatory articles and cartoons about the Jews. ${ }^{7}$ The success of the fascist regimes during the interwar years also won them many admirers from among the Turkish elite (civil and military bureaucracy, journalists, academics, artists as well as a number of cabinet ministers). The first manifestation of anti-Jewish sentiment can be found in the pogroms against the Jewish communities in Thrace in 1934, where local authorities were late to intervene and the local party organization was also responsible for the events (Aktar, 1996; Bali, 2008; Karabatak, 1996; Levi, 1996; Toumarkine \& Sigalas, 2008). The most important and best-known case of official discrimination, on the other hand, was the so-called Wealth Tax (Varlık Vergisi) of 1942-1944 that in practice targeted non-Muslim minority groups with exorbitant rates levied on them to turkify wealth and capital in Turkey (Akar, 1992; Aktar, 2000; Bali, 2010, 2012b). Turkish Jews were particularly harshly hit by the tax, which impoverished many middle class Jews, while those who could not pay the tax were sent to labor camps in eastern Turkey. ${ }^{8}$

During the Second World War, Turkey remained neutral and attempted to maintain good relations with both the belligerent camps (Deringil, 1994, 1989; Weber, 1979; Weisband, 1973). Turkish policy vis-à-vis the Holocaust was a reflection of this balancing act. It allowed a very limited number of Jewish refugees from Nazioccupied Europe to find refuge. On one hand, Turkish government did not want to antagonize Germans, who were on a winning streak at the beginning of the war and simultaneously, Turkey also took into account British policy of limiting the number of Jewish migrants to Palestine starting from 1939. Therefore, to prevent Jewish immigrants from staying in the country, Turkey did not provide transit visa for Jewish passengers unless they had valid visas for Palestine and for other transit countries where they would travel after Turkey. Moreover, Turkish authorities also expected transit passengers to prove they had tickets and enough money for the long trip (Guttstadt, 2012, pp. 194-197). ${ }^{9}$ Likewise, Turkey wanted to avoid settling - even temporarily - a large group of foreign Jews on Turkish soil, while it had difficulty in homogenizing its own society. The only exception to this policy was the invitation extended to some 550 German and Austrian Jewish citizens - professors, technicians, researchers, advisors, and their families - between 1933 and 1945 to come and work at Turkish universities and government organizations (Guttstadt, 2012, p. 177; Reisman, 2006, 2009; Schwartz, 2003; Widmann, 2000). 
In the same vein, when thousands of Turkish Jews, who had settled in Europe before the war, intended to move back to Turkey to avoid Nazi persecutions, the Turkish government dragged its feet and invented bureaucratic problems to deny their citizenship and return-despite German calls to accept them back. As a result, only some 600 Turkish Jews from France were able to travel back to safety in Turkey, ${ }^{10}$ whereas at least 2,000 Turkish Jews only from France were deported to death camps. ${ }^{11}$ Several Turkish diplomats - the best-known case is Selahattin Ülkümen, ${ }^{12}$ the Turkish consulate general in Rhodes - saved Jews by issuing them Turkish passports on their own initiative, but this they did in spite of express instructions to the contrary from Ankara. Over all, the Turkish government resolved to prevent a massive infusion of Jews to Turkey, including Turkish Jews who had formerly settled in Europe. ${ }^{13}$ Archival evidence squarely contradicts later official Turkish attempts to fabricate a "rescue myth."

Just to give short background information, the rescue myth is part of a distorted history of Turkish-Jewish friendship from 1492 through today and has been used to promote the argued positive role that Turkey has played in this history. This discourse focuses on three principal historical developments: the refuge provided by the Sultan Bayezid II for Jews expelled from Spain in 1492, invitation extended to German Jewish professors in 1933 to come to Turkey, and the rescue in Europe of Turkish Jews from the Holocaust by Turkish diplomats. Based on the importance of Holocaust memory in the Jewish Diaspora and in the Western world in general, to promote this false narrative the Quincentennial Foundation was established in Istanbul in 1989 which functioned as a common instrument of the Jewish community in Turkey and the Turkish state for lobbying activities. Indeed, since the mid-1980s, Ankara attempted to gain the backing of western Jewish communities, especially the American Jewish community, so as to counter Armenian claims for recognition of the Armenian genocide (Mallet, 2008, p. 396).

\section{Turkish Textbooks: Where is the Holocaust?}

Much work has been done in Turkey since 1990s to improve textbooks but with partial success. Studies have been conducted to determine what kind of improvements are needed in textbooks, and particularly on the subject of human rights and on how the subject of minorities and diversity should be handled to create an environment in which people from different ethnic and religious groups can live together in peace (Çayır, 2014; Çayır \& Ceyhan, 2012). In most of the cases, those recommendations came from private research institutions and civil society organizations and therefore were hardly implemented.

Indeed, this was and is an acute problem of the Turkish education system before and after the 1990s. It is evident that schools and textbooks of the nation-state regime have long ignored the fact that Turkey is home to various groups with diverse ethnic and religious backgrounds. One has to say this problem is not specific to Turkey, but it is a common denominator of all nation-states, which considered plurality a recipe for disintegration and therefore made every effort to assimilate and acculturate people of diverse backgrounds into an imagined national whole. Education happened to 
be the most significant tool available to nationalist statesmen and bureaucrats to realize the goal of leveling ethnic and religious diversity within the boundaries of nation-states.

The nascent Turkish Republic attempted to form a uniform citizenship with a singular, secular national identity and textbooks used in the Turkish education system were written from that particular perspective. Nowhere in those texts could one come across instances, anecdotes, or narratives that questioned the perspective of the holy unity of the nation and the indivisibility of its territories. Nevertheless, all these attempts failed to eradicate seething diversity in the Turkish society along ethnic, religious and sectarian lines. If anything, assimilatory policies of the Turkish authorities consolidated those differences, which would come out of the closet as Turkish democracy matured from the 1980 s to the 2000s. The 1980s witnessed the arrival of identity politics in Turkey with a host of new demands on the Turkish state for recognition. Since 1990s Kurds, Alevis, non-Muslim minority groups, the Roma, and the LGBT communities all embraced and politicized their group identities and requested equal citizenship rights coupled with an official recognition of their difference (Çayır, 2010, p. 25). Part of that recognition process, as those groups demanded, was to be reinscribed into the post-national narrative as equal participants in shared history. They also expected past crimes and offenses against their group integrity and identity to be addressed, corrected, and atoned for.

These developments have led to the questioning of the official national memory and, with the impetus provided by Turkish intellectuals and non-governmental organizations, have opened up a process of facing history and admitting historical responsibility (ibid.). In recent years, the shroud of secrecy over problematic periods of Turkish history such as the events of September 6-7, 1955, ${ }^{14}$ Dersim 1934, ${ }^{15}$ Trakya events ${ }^{16}$, the Holocaust, and Turkey's untold role in it have started to be removed and it became possible to publicly think and share perspectives about these through meetings, publications, and exhibitions. Yet, the liberalization of the political environment in Turkey did not translate into educational reforms that were meant to give voice to the excluded minority groups.

How did the Jews and the Holocaust factor into all of this? There is no academic research on the perception of Jews in Turkish textbooks before the 2000s, but one may safely assume that even if such references exist, those must have been cursory treatments of individuals from the medieval period in history textbooks or accounts of how Judaism (and Christianity) has been superseded by Islam in religion and ethics textbooks. There has been a proliferation of references to Jews as individuals and as a people in the textbooks published in the 2000s; some of the new references are in 10th and 11th grade history textbooks and others in a 12th grade contemporary global history course, which was initiated as per a ministerial decision. The new course can be taken only by less than half of all Turkish high school students, though, since it is an elective course for 12 th graders who enroll in the social sciences major in high schools. Furthermore, 12th graders spend the year preparing for the Turkish university entrance examination and it is a well-known secret that most of the teachers make time for their students to prepare by cutting material that they are supposed to teach according to the curriculum. This seriously undercuts the impact of what is taught in the contemporary global history course. 
The history textbook for 10th grade (published in 2015) describes İstanbul as a symbol of tolerance and that the city had once become a center of attraction for Jews and Christians who were being persecuted in Europe at the time (Turan, İlhan, Mehmet, Celal, \& Şenol, 2015, p. 43). The reference to the Jews continues with the story of how the Ottoman Sultan, Bayezid II, invited Jews to his realm as they had been victimized by the Spanish authorities. The book applauds the Sultan's efforts in bringing the Jews to İstanbul and resettling them in the capital city of the empire (ibid., p. 77). In the history textbook for 11 th grade, we actually come across more references to the Jews. The authors of the textbook underline freedom of religion for Armenians and Jews in the Ottoman Empire (Okur et al., 2015, p. 183). To prove this claim, they make a reference to distinct periods in Ottoman history and say how Ottoman Jews were able to establish and attend Jewish community schools, and provide figures for minority schools in the empire in 1897 (ibid., p. 196).

The textbook of the contemporary global history course (Okur et al., 2013), however, is more important in the sense that it has, by Turkish standards, a revolutionary approach to teaching history and we find in this book the only indirect reference to the Holocaust in any Turkish textbook. The book deals extensively with the interwar period (1918-1939) and the Second World War and Jews are mentioned occasionally in that context. For example, it cites a famous letter, dated September 17, 1933, from Albert Einstein addressed to Mustafa Kemal Atatürk, communicating the plea by German dissident (and mostly Jewish) professors and doctors, who were no longer able to teach and practice in Germany and, therefore, wishing to settle in and serve the Turkish Republic (ibid., p. 74).

In dealing with the Nazi regime in Germany from 1933 to 1945, the authors clearly present a damning picture of its leader and the regime by providing examples such as how the Nazis authorized the practice of state-sanctioned euthanasia, and trampled on international law by violating agreements. With the exception of the aforementioned Einstein Letter, which implies that life had become unbearable for the Jewish citizens of Germany, the authors do not expound on discriminatory laws against Jews in Germany or in German-occupied territories.

Then, the authors finally bring up the complicated issue of Nazi crimes against humanity at the end of the chapter on the war, linking the atmosphere of war with human rights violations and finishing with a lesson of morality. It is in this context that Jews are mentioned as one of the peoples, who suffered under the Nazi regime, although a specific reference to the Holocaust is not made:

(The Second World War) witnessed loss of life not only at the military fronts, but also massive civilian casualties behind the lines of engagement. Airstrikes, practices of rationing, plundering of occupied countries, murder of civilian prisoners of war, contagious diseases such as tuberculosis and typhus, and, on the other hand, the Nazi policy of creating a pure race by murdering the disabled, the Jews, the Roma, the Sinti, and people of color in concentration camps were all factors which resulted in the death of approximately 60 million people. 21 million out of the total were Soviet, 13,5 million Chinese, and 7 million German citizens. The USSR lost some $13 \%$ of its population in 1939 , Germany $10 \%$, Poland 16\%, while Western European countries and the USA were effected less by the War ... (ibid., p. 64) 
In another paragraph, the term "genocide" appears in the textbook again in the same context:

Human rights and international agreements were violated in (the Second World War). Germany, USSR and Japan, especially, acted in contravention of established roles of conduct during War and committed War crimes by maltreatment of POWs and civilian populations, summary executions, plundering ... Simultaneously, they also committed crimes against humanity by murdering individuals on the basis of political views, race and religion, by [ordering] mass killings, deportations and other inhuman activities. The Nazi Germany annihilated an important portion of Europe's Jews, Roma and political opponents by amassing them in death camps ... German Nazi rulers, political leaders of the Nazi Party and other culprits were found guilty by an international court at Nuremberg from November 1945 to October 1946. Japanese rulers were also tried before a court in 1946 in Tokyo ... Because of what happened during the Second World War, the UN General Assembly accepted the "Convention on the Prevention and Punishment of the Crime of Genocide" on December 9, 1948. Crimes against humanity committed during the War were defined as "genocide". (ibid., pp. 66-67)

No doubt, the fact that the term "genocide" appeared in a Turkish textbook in the context of human rights violations committed against the Jews (among other victim groups) is significant. In a separate box on the same page, the authors provide the text of the Genocide Convention and invite students to discover the relationship between the Second World War and the definition of genocide.

However, the language of the text is very problematic as in that it obfuscates historical facts as much as it attempts to clarify them. Most importantly, the definition of the term "genocide" is very ambiguous - probably intentionally so. It reduces genocide specifically to the period of the Second World War and implies that genocide is possible only under war conditions. This definition also seems to exclude cases of genocide that happened before or after the Second World War. Second, the text does not refer to the Nazi ideology that was bent on annihilating all the Jews, and we do not explicitly find it in the text that the Jews were actually victims of genocide. For instance, when the text provides numbers of the dead, it does so along citizenship lines. Thus, Jews as the primary target of genocide disappear in the overall death toll of the war. What is the percentage and number of the Jewish victims among the 21 million Soviet, or seven million German casualties, for example? Students get no response to this question.

Furthermore, the picture is even more blurred because the authors lump German crimes together with war crimes committed by other nations during the Second World War. Whenever Germany is mentioned in this context, it is immediately followed by the Japanese or the Soviet crimes against humanity, giving the impression that all three were committing genocide. This approach turns a blind eye to the German Nazi ideology that aimed to murder the Jews to the last individual, and hence is oblivious to the specific nature of the Holocaust. If responsibility for genocide is distributed to all three, namely, Germany, Japan, and the USSR, then students will not be able to establish a direct link between the Holocaust and the term "genocide." 


\section{Holocaust Education in Turkey: For and Against?}

Memory is an extremely contested topic in Turkey and we have already touched upon the historical baggage of Turkish-Jewish relations in the second part of this article. The very loaded nature of that relationship is now even more complicated as a result of the decline in bilateral relations between Turkey and Israel in 2008. ${ }^{17}$ The Turkish Jewish community is under increasing pressure to dissociate from Israel and feel less and less secure. ${ }^{18}$ According to Anti-Defamation League Global 100 Index in 2014 and 2015, Turkey is the 17th country with the highest scores of antisemitic views; the percentage of Turks harboring antisemitic attitudes have increased from 69 percent in 2014 to 71 percent in $2015 .{ }^{19}$ In this new terrain, there are many challenges facing future Holocaust educators, who try to inculcate Holocaust awareness into Turkish public education system.

The most profound challenge is definitely going to be the pervasive anti-Israeli and antisemitic mood in Turkey. There are quite a number of opinion leaders, usually on the fringes of the Turkish right and left, who openly express antisemitic views and disseminate them making use of widespread anti-Israeli fervor. ${ }^{20}$ On the other hand, the majority of the Turkish opinion leaders, politicians, intellectuals, and ordinary people do not attribute significance to terminology and, thus, cannot easily distinguish between Antisemitism and anti-Israeli expressions. Most of the time, they might recourse to antisemitic stereotyping, while they actually mean to blame Israel only. In other words, Antisemitism does not seem to bother the majority. This is unfortunate but remains a constant in Turkish politics and public opinion and will probably not change in the foreseeable future. Thus, all future Holocaust educators in Turkey will need to take this into consideration and devise educational strategies to deal with that reality. The obvious strategy would be to insist on separating the Holocaust from any political engagement with Israel, and to place the historical fact of extermination of Jews by the Nazi regime above and beyond Middle Eastern politics and the establishment of the State of Israel.

Second, Holocaust educators will have to take into account country-specific, negative perceptions of the Holocaust for a variety of reasons:

1. Denialism is still respectable in pockets of public opinion in Turkey, especially in the radical right-wing and Islamist circles. Well-known denialist works are published and easily available in Turkey and they are treated as academic reference works that could be used in student papers, masters and $\mathrm{PhD}$ theses, and newspaper articles. ${ }^{21}$

2. There are many who think the Holocaust is irrelevant in the Turkish context. Turkey was a neutral country during the Second World War and did not experience the horrors of the Nazi regime. Therefore, according to this view, Holocaust need not appear in Turkish public debates and need not enter school curricula. For the broader public, it is a nonissue.

3. Yet another challenge stems from people, who are not necessarily denialists or antisemites, but who object to the expanding literature on and increasing awareness about the Holocaust, because they believe the theme of Nazi genocide of the Jews has for a long time been instrumentalized and manipulated 
by the Israeli state to justify its existence and policies. These critics will continue to search for the hidden hand of Israeli agents behind all efforts to integrate Holocaust awareness into the Turkish education system.

4. Finally, some liberal-leftists in Turkey raise objections to Holocaust education in Turkey for two particular reasons. Supportive of multicultural initiatives which embrace ethnic, religious, and gender differences in Turkey, the liberal-left would actually encourage the inclusion of groups that had been historically discriminated against into the public agenda and discourse, but they argue that policy makers should have a priority list. In their eyes, Turkey has more serious and urgent issues to atone for such as facing its troubled past with Armenians and Kurds. Jews and the Holocaust do not make into the top of the liberal-left agenda, as they think this would be a waste of time and resources. Since the 1980s, the Turkish liberal-left has also been concerned that the Turkish governments exploit their relationship with Israel, the Jewish lobby in the US, and the Turkish Jewish community to divert international attention away from the Armenian Genocide in a number of ways. ${ }^{22}$ For these reasons, the one group of Turkish intellectuals who should have been pioneers of Holocaust education in Turkey refrained from doing so.

\section{Conclusion}

Teaching about the Holocaust is currently hardly a part of the Turkish education system and there is no memory of the Holocaust in Turkey despite the murder of thousands of Turkish Jews in Nazi-occupied Europe during the Holocaust. However, Turkey has officially expressed its intention to become a member state in the International Holocaust Remembrance Alliance (IHRA) - Turkey has been an observer country to the IHRA since 2008 - as well as an interest in integrating Holocaust education into its national curriculum. Therefore, for the past five years, there has been a considerable effort on the part of the Turkish government, government-supported institutions as well as several civil society organizations to organize Holocaust-related events and commemorations in Turkey. Likewise, the Turkish Jewish community under a new, younger, and more energetic leadership is increasingly vocal in facing the past and demanding atonement for past mistakes. Finally, since 2000s, authors such as Rifat Bali (1999), Corry Guttstadt (2012) ${ }^{23}$, and İzzet Bahar (2015) produced an academic literature that is making the official Turkish argument, "the rescue myth," academically obsolete and untenable, forcing a fresh new look at Turkey's entanglement with the Holocaust.

Nevertheless, while these vectors of change converge to produce positive results, we have to recognize at least one important countercurrent, which lurks on the horizon as a future challenge. If "the rescue myth" has now lost its academic credibility, it still lives on in the popular imagination and Turkey does what it can to keep this alive in Israel, in the Jewish diaspora, and in the US, where such a depiction matters most. Predictably, Israel plays the game, it does not openly question the Turkish story, and moreover it even uses its influence in Washington to advance Turkish interests, clearly to curry favor with Turkey. The discrepancy 
between academia and the realm of popular imagination will be difficult to overcome. A welcome step in that direction would be the opening of the archives of the Turkish Ministry of Foreign Affairs, which must be housing valuable information that will help future researchers to write a definitive study of the Turkish policy during the Holocaust.

\section{Notes}

1. For a very interesting analysis on the role of "as sheep to slaughter" in Jewish historical consciousness, see Yael S. Feldman (2013).

2. International Holocaust Remembrance Alliance's guidelines: http://www. holocaustremembrance.com/node/319; United States Holocaust Memorial Museum's guidelines: https://www.ushmm.org/educators/teaching-about-the-holocaust/generalteaching-guidelines; Anti-Defamation League's guidelines: http://archive.adl.org/ education/holocaust/holocaust_guidelines.html

3. This trend in teaching the Holocaust is also parallel to the developments in on the Holocaust and other genocides.

4. For an historical assessment on the Jewish and other non-Muslim Turkish citizens' situation with regard to "equal citizenship," see Rifat N. Bali (2012a).

5. "Vatandaş Türkçe Konuş!" [Citizens, speak in Turkish!] was the name given to a campaign launched in several Turkish cities starting from 1928 to push Turkish Jewish citizens to speak in Turkish as part of cultural turkification policies. A new wave of Turkish speaking campaign developed starting from 1933 and was inspired by writers such as Cevat Rifat Atilhan or Nihal Atsiz, leading figures of the Nazi antisemitic tendencies in Turkey. See Rifat N. Bali (1999, pp. 131-185, 243-245).

6. For an interesting article on the export-import theory of Antisemitism and Turkish-and Arab-only prevention programs in Germany, see in Ozyurek (2016).

7. The most famous caricature magazines disseminating anti-Jewish streotypes were Akbaba and Karikatür. These magazines were mainstream publications and were absolutely not associated with the extreme right. For a study of Jewish caricatures in Karikatür, see Laurent Mallet (1996).

8. Between January 27 and July 3, 1943, 1,232 people (all non-Muslims) were sent to labor camps in Aşkale, Erzurum. About 200 people from Izmir, Bursa, and various cities of Thrace were sent to other camps. Although the law foresaw that people above the age of 55 should be exempt from penal labor, even 75- to 80-year-old male citizens were sent to Aşkale. As a result of the severe working conditions, 21 people died in the camps. See Corry Guttstadt (2012, pp. 153-161) and Ridvan Akar (2009).

9. Between 1940 and 1944, 13,240 Jewish refugees arrived in Palestine via transit from Turkey (Guttstadt, 2012, p. 221).

10. In March 1943, the Turkish Consul in Paris sent 112 Turkish Jews from France without asking authorization by the Turkish government. All in all, some 500 Turkish Jews were rescued from France (Guttstdat, 2012, pp. 395-403). The pseudo-documentary Turkish Passport presents the repatriation of some 400 Turkish Jews from France in 1944.

11. The exact number of Turkish Jews who lost their lives during the Holocaust is unknown but we know that between 2,500 and 3,000 Jews with Turkish origins were sent to death camps and concentration camps and most of them lost their lives in these camps (Guttstadt, 2012, p. 515). We also know that only 128 Turkish Jews left Bergen-Belsen and Ravensbrück concentration camps in March 1944 and came to Turkey in the context of a civilian prisoner exchange between Turkey and Germany. 
12. Selahattin Ülkümen, wartime Turkish Consul in Rhodes, is the only Turkish consul recognized as the Righteous among the Nations by Yad Vashem for saving the lives of approximately 50 Jews, 13 of them being Turkish citizens.

13. "During the evacuation of the Marseille old port, I had informed Ankara about our Jewish subjects (exposed to the danger). In answer to that, they said, "Do not send here Jews in convoys" (excerpt from the unpublished memoirs of Behiç Erkin, wartime Turkish Ambassador to France, Behiç Erkin (n.d.), p. 542).

14. The events of September 6 to 7, is the name given to riots targeting non-Muslims of Turkey -and especially the Greek minority-living in Istanbul. The riots happened as a result of various influences: the Cyprus conflict, the negative economic conditions in the country and the resulting decline in public support for the ruling Democratic Party as well as the continuation of Turkification policies. Actually, the events should also be seen "in connection to the concept of demographic engineering, defined as any deliberate state program or policy originating from religious/ethnic discrimination or initiated for political reasons which aim to increase the political and economic power of one ethnic group over others by manipulating population through various methods", see Dilek Güven (2011).

15. The Dersim massacre (1937-1938) occured in the Kurdish district of Dersim (presently called Tunceli) as part of a military campaign by the Turkish army. The military campaign was thought by many to be a response to an internal rebellion of the region's Kurds against the government's centralization and Turkification policies. The campaign caused the death of thousands of Alevi Zazas while many others were deported to provinces in Central Anatolia. Some analysts also see the event not as a response to the rebellion but as a part of a wider policy directed against the Kurds as the military campaign was too severe for what the incident was. For further see Martin van Bruinessen (1994).

16. 1934 Thrace Events are the anti-Jewish pogroms which happened in Eastern Thrace in the summer of 1934. The incidents can be understood in light of a number of issues: Turkish-Italian tensions in the spring of 1934, and the strategic need for re-arming the demilitarized zones in Thrace and the Straits and protecting these strategic lands from Jews perceived as potential fifth columns; Jewish merchants' economic dominance in the region and finally to a lesser degree the fact that Turkish Jews were not Turkified enough. See Ayhan Aktar (1996); Avner Levi (1996); Haluk Karabatak (1996), Rifat N. Bali (2008) and Alexandre Tourmarkine and Nikos Sigalas (2002)

17. For the decline in bilateral relations, please see Aytürk (2009), Aytürk (2011), and (Bengio 2004).

18. After Israel's July 2014 attacks in Gaza, a journalist from Islamist far right Turkish daily Yeni Akit asked Turkish Chief rabbi to make an announcement in the name of the Turkish Jewish community that they don't approve Israel's "genocide in Gaza" and threatened them by saying that "otherwise, Turkish Muslim people can be overwhelmed by antisemitic feelings and that can lead to public violence against the Jewish community" (retrieved on 16 June 2016, from http://www.yeniakit.com.tr/ yazarlar/faruk-kose/hahambasina-cagri-6854.html).

19. The survey's results are retrieved on 16 June 2016, from http://globallo0.adl. org/\#country/turkey

20. For example, Soner Yalçın's book (2004), that claims to uncover the Jewish roots of Turkish elites had been reprinted more than 60 times by 2010 and sold tens of thousands of copies, while videos of an eccentric popular historian and an antisemite, Kadir Misıroğlu, had been watched are usually watched by more than 120,000 times.

21. The famous and the most influent of these books in Turkey is Roger Garaudy (2015). 
22. For an analysis of the use of Holocaust to divert international attention from the Armenian Genocide see Laurent Mallet (2008); Rifat N. Bali (2012); Rifat N. Bali (2013 b), "Perceptions of the Holocaust in Turkey" and Pinar Dost-Niyego (2016).

23. Guttstadt's book, Turkey, the Jews and the Holocaust was published first in German in 2008. In this paper the Turkish version has been used as reference.

\section{References}

Akar, R. (1992). Varlık Vergisi. Tek Parti Döneminde Azınlık Karşıtı Politika Örneği [Wealth tax. An example of anti-minority policy during the single party regime]. Belge Yayınları.

- (2009). Aşkale Yolcuları. Varlık Vergisi ve Çalışma Kampları [Aşkale passengers. The wealth tax and labor camps]. İstanbul: Doğan Kitap.

Aktar, A. (1996). 1934 Trakya Olayları ve Türk Milliyetçiliği [1934 Thrace events and Turkish nationalism]. Tarih ve Toplum, November.

- (2000). Varlık Vergisi ve Türkleştirme Politikaları [Wealth tax and Turkification policies]. İletişim.

Aytürk, İlker. (2009). Between Crises and Cooperation: The Future of Turkish-Israeli Studies., Insight Turkey, 11(2), 57-74.

- (2011). The Coming of an Ice Age? Turkish-Israeli Relations since 2002., Turkish Studies, 12(4), 675-687.

Bahar, İ. (2015). Turkey and the Rescue of European Jews. New York: Routledge.

Bali, R.N. (1999). Bir Türkleştirme Serüveni (1923-1945) [An odyssey of Turkification (1923-1945). İletişim.

_. (2008). 1934 Trakya Olaylart [1934 Thrace Events]. İstanbul: Libra.

. (2010). L'Affaire Impôt Sur la Fortune. İstanbul: Libra Kitap.

. (2012a). Model citizens of the state: The Jews of Turkey during the multi-party period. Madison-Teaneck.

. (2012b). Varlık Vergisi: Hatıralar-Tanıklıklar. [The wealth tax affair-Documents from the British national archives]. İstanbul: Libra Kitap.

—. (2013a). Toplu Makaleler-II Türkiye'de Antisemitizm ve Komplo Kültürü [Collection of Articles II: Antisemitism in Turkey and conspiracy culture]. Libra.

_. (2013b). Antisemitism and conspiracy theories in Turkey. İstanbul: Libra Kitap.

Bengio, Ofra. (2004). The Turkish-Israeli Relationship: Changing Ties of Middle Eastern Outsiders. New York: Palgrave.

Boix-Mansilla, Veronica. (2000). Historical Understanding: Beyond the Past and into the Present. In Peter N. Stearns, Peter Seixas and Sam Wineburg (Eds), Knowing, Teaching, and Learning History: National and International Perspectives (pp. 390-418). New York: New York University Press.

van Bruinessen, Martin. (1994). Genocide in Kurdistan? The suppression of the Dersim rebellion in Turkey (1937-38) and the chemical war against the Iraqi Kurds (1988). In George J. Andreopoulos (Ed.), Conceptual and historical dimensions of genocide (pp. 141-170). University of Pennsylvania Press.

Çayır, K. (2010). Yeni Bir "Biz" Anlayışı Geliştirme Yolunda Eğitim, Ders Kitapları ve Okullar. In K. Çayır (Ed.), Eğitim, Çatışma Ve Toplumsal Barış: Türkiye'den Ve Dünyadan Örnekler [Education, Conflict and Social Peace: Examples from Turkey and around the World]. İstanbul: Tarih Vakfi.

. (2014). Biz Kimiz? Ders Kitaplarında Kimlik, Yurttaşlık, Haklar [Who are we? Identity, citizenship and rights in textbooks]. Ders Kitaplarında İnsan Hakları III Projesi: Tarama Sonuçları [Human rights in textbooks project III]. İstanbul: Tarih Vakfi Publications. 
Çayır, K., \& Ceyhan, M.A. (Eds) (2012). Ayrımcılık. Çok Boyutlu Yaklaşımlar [Discrimination. Multidimension approaches]. Bilgi University Publications.

Deringil, S. (1989). Turkish foreign policy during the Second World War: An "active" neutrality. Cambridge: Cambridge University Press.

- (1994). Denge Oyunu-2. Dünya Savaşı'nda Türkiye’nin Dış Politikası [Balance game-Turkish foreign policy during the Second World War]. İstanbul: Tarih Vakfi.

Dost-Niyego, Pinar. (2016). Myths of Rescue and their Use and Abuse in Turkey. In Corry Guttstadt, Thomas Lutz, Bernd Rother and Yessica San Román (Eds), Bystanders, Rescuers or Perpetrators? The Neutral Countries and the Shoah, Metropol Verlag \& IHRA.

Erkin, B. (n.d.). Hatıratım. United States Holocaust Memorial Museum Archives. Archive no. irn36492, 2009.42

Feldman, Y.S. (2013). Not as sheep led to slaughter? On trauma, selective memory and making of historical consciousness. Jewish Social Studies, 19(3), 139-169.

Fracapane, Karel \& $\mathrm{Ha} \beta$, Matthias. (2014). (Eds), Holocaust Education in a Global Context, Paris:UNESCO. Retrieved on 29 May 2016, from http://unesdoc.unesco.org/ images/0022/002259/225973e.pdf

Garaudy, R. (2015). Israil, Mitler ve Terör [The founding myths of Israeli politics]. Istanbul: Kasim.

Guttstadt, C. (2012). Türkiye, Yahudiler ve Holokost. İstanbul: İletişim.

Güven, Dilek. (2011). Riotsagainst the Non-Muslims of Turkey: 6/7 September 1955 in the context of demographic engineering. European Journal of Turkish Studies, December. Retrieved on 17 May 2016, from https://ejts.revues.org/4538

Karabatak, H. (1996). 1934 Trakya Olayları ve Yahudiler [1934 Thrace events and the Jews]. Tarih ve Toplum, February.

Koçak, C. (2003). Türkiye'de Milli Şef Dönemi 1938-1945 [The national chief period in Turkey 1938-1945]. Illetişim, I, 502.

Kosmola, B. (November 30-December 3, 1998). Holocaust education, research, remembrance in Germany. Proceedings of the Washington Conference on HolocaustEra Assets.

Kriegel, M. (2005). Trois mémoires de la Shoah. Etats-Unis, Israël, France. Le Débât (pp. 59-72), 117.

Kurban, D. (2007). A quest for equality: Minorities in Turkey. Minority Rights Group International.

Levi, A. (1996). 1934 Trakya Yahudileri Olay1: Alınmayan Ders [1934 Thrace Jews event and lessons not learned]. Tarih ve Toplum, July.

Mallet, L. (1996). Karikatür Dergisinde Yahudilerle ilgili Karikatürler [Caricatures of Jews in the periodical "Caricature" (1936-1948)]. Toplumsal Tarih, 34, 26-33.

- (2008). La Turquie, les Turcs et les Juifs. Histoire, représentations, discours et strategies. Istanbul: Isis Press.

Novick, P. (1999). The Holocaust in American life. New York: Houghton Mifflin Co.

Ofer, D. (2009). The past that does not pass: Israelis and Holocaust memory. Israel Studies, 14(1), 1-35.

Okur, Y., Akın, S., Ertan A., Hakan, K., Mehmet, A., \& Mehmet, Ö. (2013 [2009]). Çăgdaş Türk ve Dünya Tarihi 12 [Contemporary Turkey and world history 12]. Milli Eğitim Bakanlığ [Ministry of National Education]. Okur, Y., Mehmet, A., Hakan, K., Akın, S., Mehmet, Ö., Mülver, K. (2015). Tarih 11 [History 11]. Istanbul: Ministry of National Education.

Ozyurek, Esra. (2016). Export-import theory and the racialization of antisemitism: Turkishand Arab-only prevention programs in Germany. Comparative Studies in Society and History, 58(1), 40-65. 
Reisman, A. (2006). Turkey's modernization: Refugees from Nazism and Ataturk's vision. New Academia Publishing. . (2009). Refugees and reforms: Turkey's journey. Book Surge Publishing.

Rosenfeld, A.H. (1997). The Americanization of the Holocaust. In A.H. Rosenfeld (Ed.), Thinking about the Holocaust after half a century (pp. 119-150). Bloomington and Indianapolis: Indiana University Press.

Schwartz, P. (2003). Kader Birliği: 1933 Sonrası Türkiye’ye Göç Eden Alman Bilim Adamlarl [A union of fate: Emigration of German scholars to Turkey after 1933]. İstanbul: Belge Yayınları.

Toumarkine, A., \& Sigalas, N. (2008). The 1934 Thrace events: Continuity and change within Turkish state policies regarding non-Muslim minorities. An interview with Rifat Bali. European Journal of Turkish Studies, (7). Retrieved February 28, 2016, from https://ejts.revues.org/2903

Turan, V., İlhan, G., Mehmet, Ç., Celal, G., \& Şenol, T. (2015). Tarih 10 [History 10]. Istanbul: Ministry of National Education.

Weber, F.G. (1979). The evasive neutral, Germany, Britain and the quest for a Turkish alliance in the Second World War. Columbia: University of Missouri Press.

Weisband, E. (1973). Turkish foreign policy, 1943-1955: Small state diplomacy and great power politics. Princeton, NJ: Princeton University Press.

Widmann, H. (2000). Atatürk ve Üniversite Reformu [Atatürk and the university reform]. İstanbul: Kabalc1.

Wieviorka, A. (1997). Deportation and memory: Official history and the rewriting of World War II. In A.H. Rosenfeld (Ed.), Thinking about the Holocaust after half a century (pp. 273-299). Bloomington and Indianapolis: Indiana University Press.

Yalçın, Soner (2004), Efendi: Beyaz Türklerin Büyük Sırrı, İstanbul: Doğan Kitap. 